\title{
Job characteristics, work-nonwork interference and the role of recovery strategies amongst employees in a tertiary institution
}

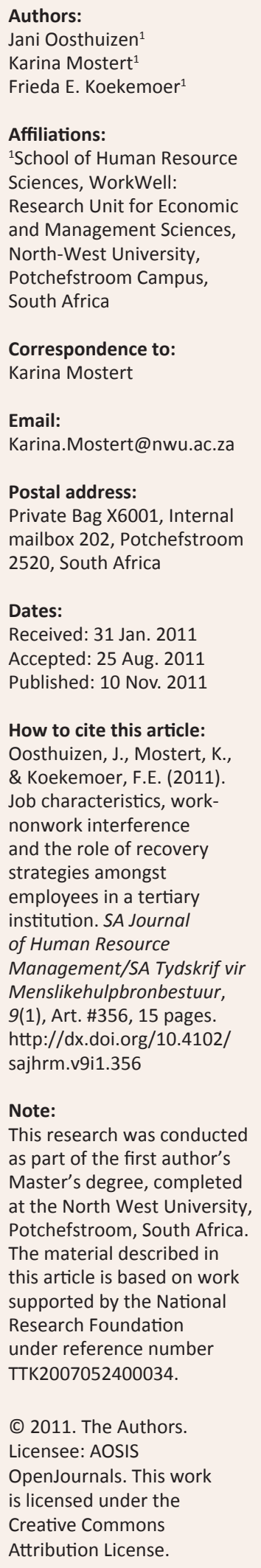

Authors:

Karina Mostert

Affiliations:

School of Human Resource

Research Unit for Economic and Management Sciences,

North-West University,

Potchefstroom Campus,

Correspondence to:

Email:

Karina.Mostert@nwu.ac.za

Private Bag X6001, Internal

mailbox 202, Potchefstroom

Dates:

Received: 31 Jan. 2011

Accepted: 25 Aug. 2011

How to cite this article:

Oosthuizen, J., Mostert, K.

nonwork interference

and the role of recovery

strategies amongst

mployees in a tertiary

Management/SA Tydskrif vir

Menslikehulpbronbestuur

Art. \#356, 15 pages.

http://dx.doi.org/10.4102/

Note:

Master's degree, completed

at the North West University,

this article is based on work

supported by the National

Research Foundation

under reference numbe

(C) 2011. The Authors.

Licensee: AOSIS

OpenJournals. This work

Creative Commons

ibution License.
Orientation: Although work characteristics and recovery strategies are associated with workfamily interference, the influence on specific types of work-nonwork interference (W-NWI) has not been investigated.

Research purpose: The aim of this study was to investigate the impact of work characteristics and recovery strategies on four types of W-NWI.

Motivation for the study: It is clear from the literature that job characteristics and W-NWI have adverse effects on employees' health and well-being. It is therefore important to identify work characteristics and recovery strategies associated with W-NWI.

Research design, approach and method: A cross-sectional survey design was used in this study. The target population was married employees with children working at a Tertiary Education Institution (TEI) in the North West Province $(N=366)$.

Main findings: Work pressure and emotional demands significantly predicted all the work-nonwork role interference dimensions. A lack of autonomy predicted work-parent interference and work-religion and/or spirituality interference, whilst a lack of development possibilities predicted work-religion and/or spirituality interference. Relaxation and mastery recovery experiences significantly predicted lower work-parent interference. A lack of psychological detachment and relaxation were significantly associated with lower workspouse interference. Relaxation and control significantly predicted lower work-domestic interference, whilst psychological detachment significantly predicted lower work-religion and/or spirituality interference.

Practical/managerial implications: The results give managers insight into the specific work characteristics and recovery experiences that play a role in W-NWI, upon which interventions can be based to address these issues.

Contribution/value-add: This study provides information on the relationship between work characteristics, recovery experiences and the effect on different types of W-NWI.

\section{Introduction}

The interference between work and the different roles in personal life is a widely studied topic in Occupational Health Psychology, mainly because of increased stressors, high job demands and/or a lack of job resources that employees experience in organisations today (Eby, Casper, Lockwood, Bordeaux \& Brinley, 2005; Geurts \& Demerouti, 2003). On an individual level, using the appropriate recovery strategies to convalesce from high demands that lead to interference between work and nonwork is crucial (e.g. De Croon, Sluiter, Blonk, Broersen \& Frings-Dresen, 2004; Geurts, Kompier, Roxburgh \& Houtman, 2003; Nýlen, Melin \& Laflamme, 2007).

Studies show that the interference between the work and nonwork domain holds negative outcomes for organisations and those they employ (Bellavia \& Frone, 2004; Boyar, Maertz, Mosley \& Carr, 2008). Work-nonwork interference (W-NWI $)^{1}$ is associated with work-related outcomes such as absenteeism (Väänänen et al., 2004), decreased job satisfaction, lower levels of organisational commitment and labour turnover intentions (Allen, Herst, Bruck \& Sutton, 2000; Duxbury, 2004; Grandey \& Cropanzano, 1999), as well as with individual outcomes such as decreased life satisfaction, marital dissatisfaction, burnout, psychosomatic complaints, depression and fatigue (Demerouti \& Geurts, 2004; Demerouti, Geurts \& Kompier, 2004; Koekemoer \&

1.A similar and closely related term is 'work-home interference', which has close similarities to the term 'work-nonwork interference'. Since work-nonwork interference encompass the interference between work and all aspects of the private life (not only the home domain), this term will be used in the current study. 
Mostert, 2006; Mostert, 2008; Peeters, De Jonge, Janssen \& Van der Linde, 2004; Peeters, Montgomery, Bakker \& Schaufeli, 2005; Van Hooff et al., 2005). W-NWI is also a reality for employees working in tertiary education institutions (TEIs), where South African TEIs find themselves in a turbulent and stressful environment (Barkhuizen \& Rothmann, 2008a, 2008b; Coetzee \& Rothmann, 2005; Jackson, Rothmann \& Van de Vijver, 2006).

According to Demerouti and Geurts (2004), jobs that have high demands and low resources are considered to be the worst working environment for individuals. When employees are confronted with too many demands at work they often lack the energy and motivation to invest time and effort into the nonwork domain (Geurts \& Demerouti, 2003). As a result one's functioning in different nonwork roles (e.g. parental, spousal, domestic and religious or spiritual) may be affected (Koekemoer \& Mostert, 2010a). When interference from the work to the nonwork domain increases, it is very likely that the need for recovery from increased load reactions will also increase (Jansen, Kant, Kristensen \& Nijhuis, 2003). If an individual does not recover sufficiently from the strain developed through the working day, it can have implications for his or her health (Geurts et al., 2005; Geurts, Rutte \& Peeters, 1999) and can affect overall well-being (Sonnentag \& Zijlstra, 2006). Insufficient recovery is also associated with high absenteeism (Meijman \& Mulder, 1998; Sonnentag \& Zijlstra, 2006), low job performance (Fritz \& Sonnentag, 2005; Sonnentag \& Geurts, 2009) and lower productivity (Moncrieff \& Pomerleau, 2000).

Although the relationship between demands and a lack of resources with work-home interference (WHI) has been researched in the South African context (e.g. Koekemoer \& Mostert, 2006; Mostert, 2008, 2009; Mostert \& Oosthuizen, 2006; Oldfield \& Mostert, 2007; Tshabalala, 2007; Van Aarde \& Mostert, 2008), the relationship with specific nonwork roles has not yet been investigated (see Koekemoer \& Mostert, 2010a, 2010b; Koekemoer, Mostert \& Rothmann, 2010). In addition, research on recovery strategies that are significantly related to work interfering with different nonwork roles, specifically in the higher education sector, is also lacking.

In light of the aforementioned discussion, the main objectives of this research were to determine, (1) which demands and resources are significant predictors of W-NWI and (2) which recovery experiences are significant predictors of W-NWI. W-NWI included work-parent interference, work-spouse interference, work-domestic interference and work-religion and/or spirituality interference. A sample of employees working in a TEI in the North West Province was used.

\section{Literature review}

\section{Work-nonwork role interference}

According to the Role Identity Theory (Stryker, 1968), roles provide individuals with a sense of meaning and purpose. Roles are attached to statures, which are defined as a position a person holds in society (Noor, 2004). When individuals hold a status, multiple roles will be associated with that status, which means that they have multiple role identities (Noor, 2004; Reitzes \& Mutran, 1994; Thoits, 1995). Thoits (1995, p. 72) defines an identity as 'a position occupied in the social structure, which is enacted in role relationships with others and viewed as descriptive of oneself'. Furthermore, Burke (1980) is of the opinion that the self is made up of a collection of identities that are linked to an individual's role relationships. These identities may be related to a work role (Geurts et al., 2005; Wiley, 1991), a parental role (Geurts et al., 2005; Simon, 1992), a spousal role (Geurts et al., 2005), a domestic role and a religious and/or spiritual role (Wilensky, 1960).

Because individuals have multiple roles, it is to be expected that some roles are more important to an individual than others. This is called 'role salience', and refers to the subjective importance that individuals attach to the various roles that they view as describing themselves (Thoits, 1995). Role identities that are viewed by an individual as more important will therefore be more salient and will result in greater commitment to that specific role (Thoits, 1995; Wiley, 1991). If various roles are salient, it is likely that conflict will arise between certain roles - specifically between the work role and other salient roles in the nonwork domain. W-NWI therefore occurs when participation in one role (e.g. the work role) makes it difficult to participate in another role (e.g. the parental or spousal role) (Greenhaus \& Beutell, 1985). Strain, or W-NWI, inevitably develops when individuals participate in multiple roles with high salience (Demerouti et al., 2004; Greenhaus \& Beutell, 1985).

W-NWI can be defined as 'the extent to which one's functioning in one domain (e.g. work) is influenced (negatively or positively) by demands from the other domain (e.g. home, nonwork) and vice versa' (Greenhaus \& Beutell, 1985). The definition suggests that either work can influence an individual's private life or an individual's private life can influence his or her work. A substantial amount of research has been carried out on the negative impact of work on the home or family domain in general (for overviews, see Byron, 2005; Eby et al., 2005; Mesmer-Magnus \& Viswesvaran, 2005). However, research concerning the impact of the work role on specific nonwork roles is limited (Aryee, 1992; Day \& Chamberlain, 2006; Small \& Riley, 1990). Recently, a new work-nonwork interference instrument was developed for employees in a TEI (Koekemoer \& Mostert, 2010b; Koekemoer et al., 2010), where W-NWI is defined as a process in which the involvement of an individual in one domain (or social role) interferes with the functioning or involvement in another domain (role), where the interference affects the way in which the worker's self-identity is influenced by external stimuli to such an extent that it results in an inadequate performance of behaviour to conform to one or more highlysalient identities or roles (Koekemoer \& Mostert, 2010a). The interference between work and four social roles (i.e. parental, spousal, domestic and religious and/or spiritual roles) was 
measured in this study. Depending on the roles that work interferes with, individuals might experience work-parent interference (WPI), work-spouse interference (WSI), workreligion and/or spirituality interference (WRI) or workdomestic interference (WDI).

\section{Job characteristics and the relationship with work-home interference}

According to the Job Demands-Resources model (Demerouti, Bakker, Nachreiner \& Schaufeli, 2001), job characteristics consist of two broad categories, namely job demands and job resources. Demerouti et al. (2001) define job demands as 'physical, social or organisational aspects of a job that require sustained physical or mental effort and are therefore associated with certain physiological and psychological costs'. Job demands such as workload (Bellavia \& Frone, 2004; Rothmann \& Essenko, 2007), time pressure (Van den Tooren \& De Jonge, 2010), long working hours (Grzywacz \& Marks, 2000), role ambiguity, role stress and stressful events (Schaufeli \& Bakker, 2004) are some of the demands reported within a stressful working environment. When employees experience job demands, it is of the utmost importance that they have adequate resources at work to overcome these demands. Job resources are those aspects of a job that are required to decrease demands, achieve work goals and objectives, and to help an individual grow and develop (Demerouti et al., 2001). Job resources exist in the task itself (such as performance feedback, skill variety or autonomy) as well as in the context of the task (for instance organisational resources such as career opportunities or job security, and social resources such as supervisor or colleague support) (Demerouti et al., 2001; Schaufeli \& Bakker, 2004).

The relationship between job demands, job resources and work-home interference has been reported in several studies (Frone, Russel \& Coopers, 1997; Geurts \& Demerouti, 2003; Janssen, Peeters, De Jonge, Houkes \& Tummers, 2004; Montgomery, Peeters, Schaufeli \& Den Ouden, 2003; Parasuraman, Purohit, Godshalk \& Beutell, 1996). These studies all found evidence that job demands and job resources are indeed related to negative WHI. In most research, negative WHI was attributed to high job demands and a lack of resources (Montgomery, Panagoplou \& Benos, 2006). Previous research also found that job demands and job resources are important predictors of health outcomes (Bakker \& Geurts, 2004; Demerouti et al., 2001; Peeters et al., 2005). According to Bakker and Geurts (2004), job demands and job resources are two aspects of work that cause a process where health impairment leads to negative WHI. High job demands and a lack of resources have been found to be related with exhaustion, somatic complaints, anxiety and insomnia, and in turn are related to a negative interference between the work and home domain (Bakker \& Geurts, 2004; Geurts et al., 2003). Between job demands and job resources, it seems that job demands are associated more with negative WHI (Demerouti \& Geurts, 2004). More specifically, work pressure, work overload and time demands predict negative WHI (Bakker \& Geurts, 2004; Geurts et al., 2003; Janssen et al., 2004; Montgomery et al., 2003). Job resources are needed to help employees cope with job demands (Bakker \& Geurts, 2004; Demerouti et al., 2001), but a lack of resources such as job control, social support (Kinnunen \& Mauno, 1998), autonomy, supervisor support and role clarity also predict negative WHI (Bakker \& Geurts, 2004; Janssen et al., 2004; Montgomery et al., 2003).

Several studies concerning the relationship between job demands, job resources and WHI have also been conducted in South Africa (Mostert \& Oosthuizen, 2006; Oldfield \& Mostert, 2007; Van Aarde \& Mostert, 2008). Significant relationships were found between job demands and negative WHI (Mostert \& Oosthuizen, 2006; Oldfield \& Mostert, 2007; Van Aarde \& Mostert, 2008). In these studies, it was found that high time demands (e.g. working overtime) (Mostert \& Oosthuizen, 2006) work overload (e.g. having excessive work to do, having too little time to complete tasks) (Van Aarde \& Mostert, 2008), high work pressure (e.g. working very hard, or working very fast or intense concentration on a task for a long period of time) (Mostert \& Oosthuizen, 2006; Oldfield \& Mostert, 2007; Van Aarde \& Mostert, 2008) and poor working conditions (e.g. working in dangerous and unsafe conditions, exposure to high security risks) (Oldfield \& Mostert, 2007) contribute to elevated levels of negative WHI. Significant relationships were also found between the lack of job resources and negative WHI (Mostert \& Oosthuizen, 2006; Van Aarde \& Mostert, 2008). It was found that a lack of role clarity (e.g. experiencing role conflict such as receiving incompatible requests from different people), a lack of colleague support (e.g. cannot count on colleagues when faced with difficulties at work, cannot ask colleagues for help), a lack of supervisor support (e.g. do not have a good relationship with your supervisor, feel unappreciated by your supervisor, cannot count on your supervisor when faced with work-related problems) and a lack of autonomy (e.g. no freedom in carrying out your own work activities, no freedom in deciding for yourself on the amount of time you wish to spend on a task) predicted negative WHI (Mostert \& Oosthuizen, 2006; Van Aarde \& Mostert, 2008).

Demands that employees in TEIs are confronted with include a high work overload, excessive time demands, role ambiguity, work pressure, administration, working overtime, managing a large amount of learners and dealing with social issues (Jackson et al., 2006; Montgomery, Mostert \& Jackson, 2005; Rothmann \& Essenko, 2007). TEIs also experience resource shortages, including poor performance feedback, job control, hampered autonomy and lack of support (Demerouti, Bakker \& Voydanoff, 2010; Jackson et al., 2006; Schaufeli \& Bakker, 2004). The lack of resources that employees face can cause them to have greater difficulty in managing the many demands they are confronted with in their jobs.

The relationships discussed thus far focus on the relationship between job demands and/or job resources and WHI. However, studies have not yet been conducted on the relationship between specific job demandsand/or job resources and interference between different roles (e.g. work 
role, parental role, spousal role, domestic role and religious or spiritual role). Nonetheless, the following hypotheses can be formulated based on the above mentioned literature findings:

- Hypothesis 1a: Job demands will be significantly related to high levels of all four types of work-nonwork interference.

- Hypothesis 1b: Available job resources will be significantly related to lower levels of all four types of work-nonwork interference.

\section{Effort-recovery and recovery experiences}

According to Nýlen et al. (2007), recovery refers to strategies or techniques that reduce tension and stress caused by everyday demands. A useful model to explain the importance of recovery is the Effort Recovery (E-R) model of Meijman and Mulder (1998). According to this model, the effort spent in responding to stressors (e.g. job demands) results in shortterm physical and psychological costs or depletion of a person's available resources. These costs accumulate and can develop into serious physical and psychological strain when sufficient recovery does not occur. Normally these costs are reversible - when recovery occurs, spent resources can be recouped. Therefore, high workload will not have negative consequences as long as recovery is sufficient during and after work. The essence of recovery is that a person's psychobiological systems that were activated whilst working should be restabilised and return to a homeostatic state in which no demands are present.

Another assumption of the E-R model is that when an individual develops strain during the working day, it does not necessarily hold health implications for him or her, as long as recovery is sufficient during the nonworking hours (Meijman, 1989). When an individual no longer has to deal with job demands, load reactions are released and recovery can begin (Meijman \& Mulder, 1998). However, when demands at work require too much effort, negative load effects build up that spill over to the nonwork domains and thus hamper one's functioning in the domain. Increasing job demands make it difficult for individuals to balance their work and nonwork lives, and the blurring between the two domains becomes more evident (Jansen et al., 2003). In a review of several studies, Geurts and Demerouti (2003) state that high job demands do interfere with an individual's private life. Therefore, when employees are confronted with too many demands at work they do not have the energy and motivation to invest time and effort into the nonwork domain (Geurts \& Demerouti, 2003) and recovery is hampered. Evidence shows that high job demands (high effort expenditure) and lack of recovery are associated with high levels of W-NWI (e.g. De Croon et al., 2003; Eby et al., 2005; Geurts et al., 2003). The insufficient recovery from the incompatible pressures within both domains can have serious implications, such as an impact on an individual's well-being (Sonnentag \& Zijlstra, 2006) and health problems, which can be severe or become chronic (Geurts et al., 1999; Geurts et al., 2005).

Recovery refers to the process where an individual's psychological and physiological stimulation returns to his or her pre-stressor level after a stressful experience (Meijman \& Mulder, 1998). Accordingly, recovery is the opposite of the strain process - it is a process of unwinding (Geurts \& Sonnentag, 2006; Sonnentag \& Fritz, 2007). Sonnentag and Fritz (2007) recently developed the Recovery Experience Questionnaire. They labelled the mechanisms that assist in recovery 'recovery experiences' and identified four recovery experiences that could be measured (Sonnentag \& Fritz, 2007):

- Psychological detachment: Psychological detachment refers to gaining mental distance from one's job. It goes beyond the physical absence from the workplace - being physically away from one's job does not mean that recovery necessarily takes place (Sonnentag \& Fritz, 2007). For this recovery strategy to be sufficient, it is important for an employee not to be involved in any work-related activities such as reading e-mails, taking work-related telephone calls, etc. (Sonnentag \& Bayer, 2005; Sonnentag \& Kruel, 2006). This means an individual has to be completely mentally disengaged from work. According to the questionnaire development study of Sonnentag and Fritz (2007), psychological detachment correlates positively with variables such as emotion-focused coping (attempts to manage cognitions or emotions directly, without changing the environment), emotional stability (having good emotional adjustment to various events) and life satisfaction (the judgment of a person's quality of life).

- Relaxation: Relaxation is commonly associated with leisure activities and is characterised by a state of low activation and increased positive affect (Sonnentag \& Fritz, 2007). Relaxation can occur on a physical or mental level. On a physical level, relaxation can occur through reading a book, listening to music or taking a quiet walk (Fritz \& Sonnentag, 2006). On a mental level, relaxation can, for example, be achieved through meditation (Sonnentag \& Fritz, 2007). Relaxation therapies calm an individual and reduce increased sympathetic responses such as accelerated heart rate and high blood pressure in order to minimise harmful effects caused by stress (Stein, 2001). Relaxation is important for recovery, as prolonged activation caused by stressful work should be reduced in order to restore an individual's pre-stressor state (Brosschot, Pieper \& Thayer, 2005). Sonnentag and Fritz (2007) found positive correlations between relaxation and emotion-focused coping, emotional stability and life satisfaction.

- Mastery: Mastery experiences refer to activities that act as a challenge for an individual or that provide new skills that can be learnt (Sonnentag \& Fritz, 2007). The mastery experience should be a challenge, but should not in any way overtax the person's capabilities. Examples of mastery experiences include learning a new language, playing an instrument or going on a mountain climbing expedition (Fritz \& Sonnentag, 2006). Taking up mastery experiences requires self-regulation, thus exerting control over the chosen activity by practising or attending classes (Sonnentag \& Fritz, 2007). Mastery experiences may seem 
to place additional demands on the individual. However, these experiences are expected to result in recovery, because they help to build up new internal resources (e.g. skills, competencies and self-efficacy) (Bandura, 1997). Sonnentag and Fritz (2007) found that mastery experiences correlated positively with job control (an individual's own discretion to determine timing and working method), problem-focused coping (includes problem-solving behaviours and aims at resolving the stressor), emotionfocused coping, openness to experience (an individual's creativity, flexibility and willingness to take risks), conscientiousness (an individual's self-discipline and achievement orientation), emotional stability and life satisfaction.

- Control during leisure time: According to Sonnentag and Fritz (2007), control is a person's ability to choose an action from two or more options. Furthermore, control refers to an individual having the choice of the activity he or she wants to pursue during leisure time and when and how he or she would like to pursue the activity. An individual's well-being can be increased when he or she feels in control of certain life domains (Bandura, 1997). The experience of control during leisure time may increase an individual's self-efficacy and feelings of competency, which can enhance well-being (Sonnentag \& Fritz, 2007). Therefore, control may act as an external resource that enhances recovery from work during off-work time. In addition, control during leisure time gives an individual the chance to choose an activity to pursue and this may be especially supportive for the recovery process (Sonnentag \& Fritz, 2007). Sonnentag and Fritz (2007) found positive correlations between control during leisure time and job control, problem-focused coping, emotion-focused coping, emotional stability and life satisfaction.

Studies on the relationship between recovery experiences and interference between work and specific nonwork roles have not yet been conducted. The reason is that recovery questionnaires are scarce. Recently, Sonnentag and Fritz (2009) developed a new questionnaire for the measurement of recovery. However, this questionnaire has not yet been used to measure the relationship between recovery experiences (psychological detachment, relaxation, mastery and control) and W-NWI. According to Eden (2001), adequate recovery from work pressure is needed to minimise or avoid negative health effects; however, limited studies in the work-home literature focus on recovery-related concepts (MorenoJiménez et al., 2009).

Sonnentag and Kruel (2006) conducted a study on the relationship between job stressors (i.e. workload) and psychological detachment. Their results showed a negative relationship between high work pressure and psychological detachment. Sonnentag and Fritz (2007) conducted a study on recovery experiences and potential predictors (e.g. work situation variables, coping and personality) as well as potential consequences (e.g. psychological well-being). They found that three of the four experiences were related to job stressors. A rather high negative correlation existed between time pressure and psychological detachment. Relaxation was related to quantitative workload but not to job stressors. Job stressors were not related to mastery experiences, and job control was not related to psychological detachment, relaxation or mastery. Furthermore, they found mostly nonsignificant and generally low correlations between coping measures and recovery experiences. In addition, generally low correlations were found between personality and recovery experiences. Recovery experiences were related to most of the psychological well-being indicators. Fox, Tange and Perez (2008) also conducted a study that examined the potential interaction between job stressors (i.e. work pressure) and recovery experiences to see if these experiences buffer the negative effects of stressful job demands and health. They found significant interactions between interpersonal conflict and mastery, which predicted physical symptoms. There was also an interactive effect between conflict and mastery in predicting gastrointestinal problems and headaches, as well as between workload and mastery in predicting gastrointestinal problems.

Moreno-Jiménez et al. (2009) conducted a study that linked work-family conflict and family-work conflict with the concept of recovery. They also studied psychological detachment from work as moderators between the relationship of these two types of conflict with two indicators of well-being, namely psychological strain and life satisfaction. They found that psychological detachment from work lessens some of the negative effects of work-family conflict on employees' well-being. In addition, psychological detachment from work moderates the relationship between work-family conflict and psychological strain, and the relationship between family-work conflict and life satisfaction. In addition, Siltaloppi, Kinnunen and Feldt (2009) conducted a study on the direct and moderator roles of the recovery experiences in the relationship between psychosocial work characteristics (i.e. time demands, job control and justice of the supervisor) and occupational well-being (i.e. need for recovery, job exhaustion and work engagement). The results showed that psychological detachment and mastery are protective mechanisms against an increased need for recovery in a situation where there was a lack of job control. Relaxation protected against increased job exhaustion under high time demands. Furthermore, psychological detachment and mastery in particular had direct associations with occupational well-being. The general findings of this study showed that recovery experiences play an important role in maintaining overall well-being at work. Based on these findings, the following hypotheses can be formulated with regards to the relationship between recovery strategies and W-NWI:

- Hypothesis 2a: Psychological detachment will be significantly related to lower levels of all four types of W-NWI.

- Hypothesis 2b: Relaxation will be significantly related to lower levels of all four types of W-NWI.

- Hypothesis 2c: Mastery will be significantly related to lower levels of all four types of W-NWI. 
- Hypothesis 2d: Control will be significantly related to lower levels of all four types of W-NWI.

\section{Research design Research approach}

A cross-sectional survey design was used. With a crosssectional survey design researchers are able to assess interrelationships amongst variables within a population (Struwig \& Stead, 2001). Cross-sectional designs entail the collection of data on more than one case at a single point in time, after which the data is examined to detect patterns of association (Bryman \& Bell, 2003). With cross-sectional designs there is no time ordering to the variables; it is thus only possible to examine relationships between variables, which make this design suitable for this study.

\section{Research method}

\section{Research participants}

A cross-sectional survey research design was conducted. Because the four dimensions of the W-NWI scale are of particular relevance for married employees with children (two of the four scales measure interference between work and the role of spouse and parent), only married parents and partners living together with children were included. These employees were employed by a TEI in the North West Province. A total of 650 questionnaires were distributed, of which 366 were returned (response rate $=56 \%$ ). The majority of the participants were White $(80.35 \%)$, whilst $14.75 \%$ were African, 3\% were Coloured and $0.80 \%$ were Indian. Almost two-thirds of the participants were women $(65 \%)$, whilst $34.70 \%$ were men. In terms of the position the participants fulfilled at work, $26.77 \%$ were administrative assistants, $9.84 \%$ were secretaries and $16.678 \%$ were administrative officers. Of the academic staff, $9.84 \%$ were lecturers, $11.46 \%$ were senior lecturers, $6.56 \%$ were associate professors and $7.10 \%$ were professors.

\section{Measuring instruments}

The following measuring instruments were used in the empirical study:

Job demands: Three job demands were measured, namely work pressure, emotional demands and cognitive demands. All items were scored on a four-point Likert scale ranging from 0 ('never') to 3 ('always'). Work pressure was measured with a three-item scale developed by Bakker, Demerouti and Schaufeli (2003a). An example of an item is: 'How often does it happen that you have to work extra hard in order to meet your deadlines?'. Emotional demands were measured with the five-item scale developed by Bakker et al. (2003b). An example of an item is: 'How often does it happen that your work is emotionally draining?'. Cognitive demands were measured with the four-item scale developed by Peeters et al. (2005). An example of an item is: 'How often does it happen that your work requires you to concentrate continuously?'. Reliable Cronbach alpha coefficients larger than 0.70 (Nunnally \&
Bernstein, 1994) were found in these studies: work pressure, $\alpha=0.76$; emotional job demands, $\alpha=0.74$; and cognitive job demands, $\alpha=0.89$ (Bakker et al., 2003b; Peeters et al., 2005).

Job resources: Three job resources were measured, including autonomy, social support and job developmental possibilities. Autonomy was measured with the scale developed by Bakker, Demerouti and Verbeke (2004) and included three items (e.g. 'How often does it happen that you have freedom in carrying out your work-related duties?'). Social support was measured with a scale developed by Bakker et al., (2003c) with three items (e.g. 'How often does it happen that you ask your colleagues help if necessary'). Job developmental possibilities were assessed by items that were conceptually mirrored from existing scales of home developmental possibilities developed by Demerouti et al. (2010). Three items were used to assess job developmental possibilities (e.g. 'How often does it happen that you can develop yourself sufficiently in your work?'). All these items were rated on a four-point Likert scale ranging from 0 ('never') to 3 ('always'). Cronbach alpha coefficients reported ranged between 0.68 and 0.74 for autonomy and between 0.81 and 0.85 for social support (Bakker et al., 2004; Bakker, Demerouti \& Euwema, 2005).

Work-nonwork interference: A newly developed instrument by Koekemoer et al. (2010) was used to measure interference between work and four nonwork roles. Workparent interference was assessed with three items (e.g. 'How often does it happen that your work keeps you from your child(ren) more than you like?'). Work-spouse interference was assessed with four items (e.g. 'How often does it happen that your marriage or relationship with your spouse or partner suffers because of your work?'). Work-domestic interference was assessed with three items (e.g. 'How often does it happen that because of your work arrangements, you find it difficult to fulfil your domestic obligations?'). Work-religion and/or spirituality interference was assessed with four items (e.g. 'How often does it happen that your work interferes with your religion or spirituality?'). All items were rated on a fourpoint Likert scale ranging from 0 ('never') to 3 ('always'). Functioning of the items was tested with Rasch analyses, and the construct validity, discriminant validity and convergent validity were confirmed (Koekemoer et al., 2010; Koekemoer \& Mostert, 2010b). Reliable Cronbach alpha coefficients were also obtained for the four scales: work-parent interference ( $\alpha=0.88)$; work-spouse interference $(\alpha=0.88)$; work-domestic ( $\alpha=0.91)$; and work-religion and/or spirituality interference $(\alpha=0.86)$.

Recovery: The 'Recovery Experiences Questionnaire' of Sonnentag and Fritz (2007) was used to measure the four recovery experiences: psychological detachment (three items, e.g. 'I forget about work'), relaxation (three items, e.g. 'I take time for leisure'), mastery (four items, e.g. 'I do things that challenge me'); and control (four items, e.g. 'I determine my own schedule'). Items were rated on a five-point scale ranging from 1 ('I do not agree at all') to 5 ('I fully agree'). The following alpha coefficients were obtained from the crossvalidation sample of Sonnentag and Fritz (2007) for the four 
recovery experiences: psychological detachment $(\alpha=0.85)$; relaxation ( $\alpha=0.85)$; mastery $(\alpha=0.85)$; and control $(\alpha=0.85)$. Mostert and Els (in press) also confirmed the validity and reliability of the survey in a sample of employees in a TEI.

\section{Research procedure}

Permission was obtained from the ethics committees of the participating institutions to distribute the questionnaires amongst the employees who fit the criteria. Lists of married employees with children were obtained from various faculties and departments. Deans of the different faculties were approached for permission to conduct the study in their faculties and the participation of their personnel was requested. Questionnaires were distributed to participants with the help of field workers. When the questionnaires were handed out, a collection date was arranged with the participants. Participants could choose how they wanted to return the questionnaire (e.g. internal post, personal collection or personal delivery). These options were given in order to ensure anonymity and confidentiality. Participants were allowed two to three weeks to complete and return the questionnaires. Included in the questionnaires was an information letter explaining the purpose of the survey, the assurance of anonymity and confidentiality, and details on how information would be dealt with in order to ensure privacy.

\section{Statistical analysis}

The statistical analysis was conducted with the SPSS program (SPSS Inc., 2009). Descriptive statistics (e.g. means and standard deviations) and inferential statistics were used to analyse the data. Cronbach alpha coefficients were used to assess the reliability of the constructs. Pearson productmoment correlation coefficients were used to specify the relationship between the variables. In terms of statistical significance, it was decided to set the value at a $95 \%$ confidence interval level ( $p \leq 0.05)$. Effect sizes were used to decide on the practical significance of the findings. A cut-off point of 0.30 (medium effect) and 0.50 (large effect) (Cohen, 1988) was set for the practical significance of correlation coefficients. Hierarchical multiple regression analysis were carried out to determine the percentage variance in the dependent variables (the four W-NWI dimensions) that were predicted by the independent variables (e.g. job demands, job resources and the four recovery experiences) and to determine which recovery experiences are significant predictors of W-NWI.

\section{Results \\ Descriptive statistics and product-moment correlations}

The descriptive statistics and Cronbach alpha coefficients of the measuring instruments as well as the product-moment correlation coefficients between the constructs are reported in Table 1.

From the results in Table 1 it can be seen that the Cronbach alpha coefficients of all the measuring instruments were considered acceptable compared to the guideline of $\alpha \geq$ 0.70 (Nunnally \& Bernstein, 1994). Furthermore, Table 1 provides the correlation coefficients of the study variables. Work-parent interference, work-spouse interference and work-domestic interference were statistically and practically related, with a large effect, to work pressure, emotional demands, relaxation and control. Work-parent interference and work-spouse interference were statistically and practically significantly related, with a medium effect, to autonomy and psychological detachment. Work-parent interference and work-domestic interference were also statistically and practically related, with a large effect, to mastery. Work-religion and/or spirituality interference was statistically and practically related, with a medium effect, to work pressure, psychological detachment and control, but statistically and practically related, with a large effect, to emotional demands. Work-domestic interference was statistically related to cognitive demands, work autonomy, support and developmental possibilities. Work-religion and/or spirituality interference was statistically related to cognitive demands, work autonomy, support, relaxation

TABLE 1: Correlation coefficients between job demands, job resources, recovery experiences and work-nonwork interference.

\begin{tabular}{|c|c|c|c|c|c|c|c|c|c|c|c|c|c|c|c|c|}
\hline Dimensions & $\mathbf{M}$ & SD & $\alpha$ & 1 & 2 & 3 & 4 & 5 & 6 & 7 & 8 & 9 & 10 & 11 & 12 & 13 \\
\hline 1. Work pressure & 1.46 & 0.72 & 0.83 & 1.00 & & & & & & & & & & & & \\
\hline 2. Emotional demands & 0.90 & 0.56 & 0.84 & $0.48^{*}$ & 1.00 & & & & & & & & & & & \\
\hline 3. Cognitive demands & 2.01 & 0.63 & 0.71 & $0.56^{*}$ & $0.35^{*}$ & 1.00 & & & & & & & & & & \\
\hline 4. Autonomy & 1.69 & 0.62 & 0.67 & $-0.15^{*}$ & $-0.24 *$ & -0.01 & 1.00 & & & & & & & & & \\
\hline 5. Support & 1.90 & 0.67 & 0.75 & $-0.28 *$ & $-0.43^{*}$ & $-0.16^{*}$ & $0.47^{*}$ & 1.00 & & & & & & & & \\
\hline 6. Developmental possibilities & 1.74 & 0.69 & 0.81 & -0.02 & $-0.14^{*}$ & 0.07 & $0.56^{*}$ & $0.41^{*}$ & 1.00 & & & & & & & \\
\hline 7. Psychological detachment & 2.86 & 1.05 & 0.84 & $-0.33^{*}$ & $-0.24^{*}$ & $-0.22 *$ & $0.19^{*}$ & $0.29 *$ & 0.05 & 1.00 & & & & & & \\
\hline 8. Relaxation & 3.42 & 0.91 & 0.86 & $-0.39 *$ & $-0.31 *$ & $-0.23 *$ & $0.28^{*}$ & $0.30 *$ & $0.28^{*}$ & $0.46^{*}$ & 1.00 & & & & & \\
\hline 9. Mastery & 3.35 & 0.91 & 0.88 & $-0.22 *$ & $-0.27^{*}$ & -0.10 & $0.29 *$ & $0.26^{*}$ & $0.34^{*}$ & $0.23 *$ & $0.66^{*}$ & 1.00 & & & & \\
\hline 10. Control & 3.55 & 0.85 & 0.86 & $-0.32 *$ & $-0.30 *$ & $-0.17 *$ & $0.34^{*}$ & $0.33^{*}$ & $0.26^{*}$ & $0.38^{*}$ & $0.69^{*}$ & $0.62^{*}$ & 1.00 & & & \\
\hline 11. Work-parent interference & 0.91 & 0.77 & 0.88 & $0.48^{*}$ & $0.52 *$ & $0.29 *$ & $-0.33^{*}$ & $-0.32 *$ & $-0.21 *$ & $-0.31 *$ & $-0.51^{*}$ & $-0.45^{*}$ & $-0.46^{*}$ & 1.00 & & \\
\hline 12. Work-spouse interference & 0.67 & 0.63 & 0.88 & $0.52^{*}$ & $0.58^{*}$ & $0.29 *$ & $-0.24 *$ & $-0.35^{*}$ & $-0.13^{*}$ & $-0.37 *$ & $-0.46^{*}$ & $-0.34 *$ & $-0.42 *$ & $0.68^{*}$ & 1.00 & \\
\hline 13. Work-domestic interference & 0.92 & 0.78 & 0.92 & $0.55^{*}$ & $0.48^{*}$ & $0.28^{*}$ & $-0.28^{*}$ & $-0.29 *$ & $-0.16^{*}$ & $-0.36^{*}$ & $-0.51^{*}$ & $-0.43^{*}$ & $-0.50 *$ & $0.78^{*}$ & $0.75^{*}$ & 1.00 \\
\hline $\begin{array}{l}\text { 14. Work-religion and/or } \\
\text { spirituality interference }\end{array}$ & 0.40 & 0.54 & 0.86 & $0.38^{*}$ & $0.42^{*}$ & $0.21 *$ & $-0.26 *$ & $-0.25^{*}$ & -0.06 & $-0.33^{*}$ & $-0.35^{*}$ & $-0.29 *$ & $-0.37^{*}$ & $0.54 *$ & $0.61^{*}$ & $0.55^{*}$ \\
\hline
\end{tabular}

$\mathrm{M}$, mean; SD, standard deviation.

All correlations $r \geq 0.30$ are practically significant (medium effect); $r \geq 0.50$ (large effect).

*, Statistically significant $(p \leq 0.05)$ 
and mastery. Work-parent interference and work-spouse interference were statistically related to cognitive demands and developmental possibilities.

\section{Multiple regression analysis}

To determine which recovery experiences predict the four types of W-NWI, four Hierarchical multiple regression analyses, using the enter method, were performed. It was decided to control for demographic characteristics in the first step of each regression. Job demands were entered in the second step, job resources in the third step, and recovery experiences in the fourth and final step of each regression. The results are reported in Table 2, 3, 4 and 5.

Table 2 summarises the regression analysis with year of birth, gender, job demands, job resources and recovery experiences as predictors of work-parent interference. As can be seen, the final model was statistically significant $\left(F_{(12,35)}=24.64\right.$; $p<0.00$ ) accounting for approximately $46 \%$ of the variance in work-parent interference. More specifically, it seems that work pressure $(\beta=0.19 ; t=3.58 ; p \leq 0.05)$, emotional demands $(\beta=0.29 ; t=5.81 ; p \leq 0.05)$, work autonomy $(\beta=-0.12 ; t=-2.39 ; p \leq 0.05)$, relaxation $(\beta=-0.16 ; t=-2.43$; $p \leq 0.05)$ and mastery $(\beta=-0.14 ; t=-2.49 ; p \leq 0.05)$ predict work-parent interference.

Table 3 summarises the regression analysis with year of birth, gender, job demands, job resources and recovery experiences as predictors of work-spouse interference. The final model was statistically significant $\left(F_{(12,35)}=28.33\right.$; $p<0.00$ ) accounting for $50 \%$ of the variance in work-spouse interference. More specifically, it seems that work pressure $(\beta=0.21 ; t=4.04 ; p \leq 0.05)$, emotional demands $(\beta=0.40$, $t=8.43 ; p \leq 0.05)$, psychological detachment $(\beta=-0.09$; $t=-2.06 ; p \leq 0.05)$ and relaxation $(\beta=-0.15 ; t=-2.31 ; p \leq 0.05)$ predict work-spouse interference.

Table 4 summarises the regression analysis with year of birth, gender, job demands, job resources and recovery experiences as predictors of work-domestic interference. Again, the final model was statistically significant $\left(F_{(12,35)}=27.61\right.$; $p<0.00)$ accounting for $49 \%$ of the variance in work-domestic interference. More specifically, it seems that gender $(\beta=0.09$; $t=2.15 ; p \leq 0.05)$, work pressure $(\beta=0.34 ; t=6.50 ; p \leq 0.05)$, emotional demands $(\beta=0.21 ; t=4.43 ; p \leq 0.05)$, relaxation

TABLE 2: Multiple regression analysis with work-parent interference as dependent variable.

\begin{tabular}{|c|c|c|c|c|c|c|c|c|c|c|}
\hline \multirow[t]{2}{*}{ Model } & \multirow[t]{2}{*}{ Independent variables } & \multicolumn{2}{|c|}{$\begin{array}{l}\text { Unstandardised } \\
\text { coefficients }\end{array}$} & \multirow{2}{*}{$\begin{array}{c}\begin{array}{c}\text { Standardised } \\
\text { coefficients }\end{array} \\
\text { Standardised Beta }(\boldsymbol{\beta})\end{array}$} & \multirow[t]{2}{*}{$t$} & \multirow[t]{2}{*}{$p$} & \multirow[t]{2}{*}{$F$} & \multirow[t]{2}{*}{$R$} & \multirow[t]{2}{*}{$R^{2}$} & \multirow[t]{2}{*}{$\Delta \boldsymbol{R}^{2}$} \\
\hline & & Beta $(\beta)$ & SE & & & & & & & \\
\hline \multirow[t]{3}{*}{1} & (Constant) & -1.34 & 9.05 & - & -0.15 & 0.88 & 1.78 & 0.10 & 0.01 & 0.01 \\
\hline & Age & 0.00 & 0.01 & 0.01 & 0.24 & 0.81 & - & - & - & - \\
\hline & Gender & 0.16 & 0.09 & 0.10 & 1.80 & 0.07 & - & - & - & - \\
\hline \multirow[t]{6}{*}{2} & (Constant) & -1.16 & 7.54 & - & -0.15 & 0.88 & 36.02 & 0.58 & 0.34 & 0.33 \\
\hline & Age & 0.00 & 0.00 & 0.01 & 0.14 & 0.89 & - & - & - & - \\
\hline & Gender & 0.15 & 0.07 & 0.09 & 2.06 & $0.04 *$ & - & - & - & - \\
\hline & Work pressure & 0.34 & 0.06 & 0.31 & 5.58 & $0.00 *$ & - & - & - & - \\
\hline & Emotional demands & 0.50 & 0.07 & 0.36 & 7.27 & $0.00 *$ & - & - & - & - \\
\hline & Cognitive demands & -0.02 & 0.07 & -0.02 & -0.28 & 0.78 & - & - & - & - \\
\hline \multirow[t]{9}{*}{3} & (Constant) & -0.59 & 7.36 & - & -0.08 & 0.94 & 26.38 & 0.61 & 0.38 & 0.04 \\
\hline & Age & 0.00 & 0.00 & 0.01 & 0.13 & 0.89 & - & - & - & - \\
\hline & Gender & 0.10 & 0.07 & 0.06 & 1.46 & 0.15 & - & - & - & - \\
\hline & Work pressure & 0.31 & 0.06 & 0.29 & 5.24 & $0.00 *$ & - & - & - & - \\
\hline & Emotional demands & 0.44 & 0.07 & 0.32 & 6.09 & $0.00 *$ & - & - & - & - \\
\hline & Cognitive demands & 0.03 & 0.07 & 0.02 & 0.40 & 0.69 & - & - & - & - \\
\hline & Autonomy & -0.21 & 0.07 & -0.17 & -3.08 & $0.00 *$ & - & - & - & - \\
\hline & Support & 0.02 & 0.06 & 0.01 & 0.25 & 0.80 & - & - & - & - \\
\hline & Developmental possibilities & -0.07 & 0.06 & -0.07 & -1.24 & 0.22 & - & - & - & - \\
\hline \multirow[t]{13}{*}{4} & (Constant) & 6.06 & 7.00 & - & 0.87 & 0.87 & 24.64 & 0.68 & 0.46 & 0.09 \\
\hline & Age & -0.00 & 0.00 & -0.03 & -0.65 & 0.52 & - & - & - & - \\
\hline & Gender & 0.06 & 0.07 & 0.04 & 0.88 & 0.38 & - & - & - & - \\
\hline & Work pressure & 0.21 & 0.06 & 0.19 & 3.58 & $0.00 *$ & - & - & - & - \\
\hline & Emotional demands & 0.39 & 0.07 & 0.29 & 5.81 & $0.00 *$ & - & - & - & - \\
\hline & Cognitive demands & 0.02 & 0.07 & 0.02 & 0.33 & 0.75 & - & - & - & - \\
\hline & Autonomy & -0.15 & 0.06 & -0.12 & -2.39 & $0.02 *$ & - & - & - & - \\
\hline & Support & 0.05 & 0.06 & 0.04 & 0.86 & 0.39 & - & - & - & - \\
\hline & Developmental possibilities & -0.00 & 0.06 & -0.00 & -0.07 & 0.94 & - & - & - & - \\
\hline & Psychological detachment & -0.03 & 0.04 & -0.04 & -0.73 & 0.47 & - & - & - & - \\
\hline & Relaxation & -0.13 & 0.05 & -0.16 & -2.43 & $0.02 *$ & - & - & - & - \\
\hline & Mastery & -0.12 & 0.05 & -0.14 & -2.49 & $0.01 *$ & - & - & - & - \\
\hline & Control & -0.07 & 0.05 & -0.07 & -1.23 & 0.22 & - & - & - & - \\
\hline
\end{tabular}

$\mathrm{SE}$, standard error; $t, t$-statistic; $p$, statistical significance; $F$, F-statistic; $R$, square root of R-square (correlation between the observed and predicted values of the dependent variable); $R^{2}$, proportion of variance in the dependent variable explained by the independent variables; $\Delta R^{2}$, change in percentage variance explained by next step in model.

*, Statistically significant $p \leq 0.05$ 
$(\beta=-0.13 ; t=-2.06 ; p \leq 0.05)$ and control $(\beta=-0.14 ; t=-2.50 ;$ $p \leq 0.05)$ predict work-domestic interference.

Table 5 summarises the regression analysis with year of birth, gender, job demands, job resources and recovery experiences as predictors of work-religion and/or spirituality interference. The final model was statistically significant $\left(F_{(12,35)}=13.45\right.$; $p<0.00)$ accounting for $32 \%$ of the variance in work-religion and/or spirituality interference. More specifically, it seems that work pressure $(\beta=0.14 ; t=2.37 ; p \leq 0.05)$, emotional demands $(\beta=0.28 ; t=5.02 ; p \leq 0.05)$, work autonomy $(\beta=-0.17 ; t=-2.99 ; p \leq 0.05)$, developmental possibilities $(\beta=0.13 ; t=2.17 ; p \leq 0.05)$ and psychological detachment $(\beta=-0.11 ; t=-2.15 ; p \leq 0.05)$ predict work-religion and/ or spirituality interference. Based on these results, partial support was found for Hypothesis 1 and 2.

\section{Discussion}

The objective of this study was to determine which demands and resources are significant predictors of W-NWI of employees working in a TEI, and which recovery experiences are significant in dealing with high levels of W-NWI caused by high demands and a lack of resources.
The results indicate that work pressure and emotional demands were the two job demands that significantly predicted all the work-nonwork role interference dimensions. Of the included job resources, autonomy predicted workparent interference and work-religion and/or spirituality interference, whilst development possibilities predicted work-religion and/or spirituality interference. Based on these results, it seems that employees from the TEI who experience high work pressure (i.e. working very hard with not enough time to complete tasks or concentrating intensely on tasks for long periods) and high levels of emotional demands (i.e. being in emotional stressful situations at work) have difficulties in combining their work and nonwork roles and thus experience negative interference from the work domain to the nonwork domain. Therefore, when demands are high, employees' relationships with their child(ren), spouse, home life and religion suffer. However, employees who have autonomy in their jobs (i.e. freedom in carrying out own work activities, freedom in deciding the time spent on a task) experience significantly less work-parent interference and work-religion and/or spirituality interference. Interestingly, employees who have high developmental possibilities (i.e. the opportunity to develop strong points and to learn new

TABLE 3: Multiple regression analysis with work-spouse interference as dependent variable.

\begin{tabular}{|c|c|c|c|c|c|c|c|c|c|c|}
\hline \multirow[t]{2}{*}{ Model } & \multirow[t]{2}{*}{ Independent variables } & \multicolumn{2}{|c|}{$\begin{array}{l}\text { Unstandardised } \\
\text { coefficients }\end{array}$} & \multirow{2}{*}{$\begin{array}{c}\begin{array}{c}\text { Standardised } \\
\text { coefficients }\end{array} \\
\text { Standardised Beta }(\boldsymbol{\beta}) \\
\end{array}$} & \multirow[t]{2}{*}{$t$} & \multirow[t]{2}{*}{$p$} & \multirow[t]{2}{*}{$F$} & \multirow[t]{2}{*}{$R$} & \multirow[t]{2}{*}{$R^{2}$} & \multirow[t]{2}{*}{$\Delta \boldsymbol{R}^{2}$} \\
\hline & & Beta $(\beta)$ & SE & & & & & & & \\
\hline \multirow[t]{3}{*}{1} & (Constant) & 6.45 & 7.45 & - & 0.87 & 0.34 & 0.61 & 0.06 & 0.00 & 0.00 \\
\hline & Age & -0.00 & 0.00 & -0.04 & -0.77 & 0.44 & - & - & - & - \\
\hline & Gender & -0.05 & 0.07 & -0.03 & -0.64 & 0.52 & - & - & - & - \\
\hline \multirow[t]{6}{*}{2} & (Constant) & 7.86 & 5.78 & - & 1.36 & 0.17 & 51.67 & 0.65 & 0.42 & 0.42 \\
\hline & Age & -0.00 & 0.00 & -0.06 & -1.37 & 0.17 & - & - & - & - \\
\hline & Gender & -0.06 & 0.05 & -0.04 & -1.03 & 0.31 & - & - & - & - \\
\hline & Work pressure & 0.28 & 0.05 & 0.32 & 6.03 & $0.00 *$ & - & - & - & - \\
\hline & Emotional demands & 0.52 & 0.05 & 0.46 & 9.84 & $0.00 *$ & - & - & - & - \\
\hline & Cognitive demands & -0.05 & 0.06 & -0.04 & -0.87 & 0.39 & - & - & - & - \\
\hline \multirow[t]{8}{*}{3} & (Constant) & 7.79 & 5.76 & - & 1.35 & 0.18 & - & - & - & - \\
\hline & Age & -0.00 & 0.00 & -0.06 & -1.32 & 0.19 & - & - & - & - \\
\hline & Gender & -0.07 & 0.06 & -0.06 & -1.32 & 0.19 & - & - & - & - \\
\hline & Emotional demands & 0.47 & 0.06 & 0.42 & 8.49 & $0.00 *$ & - & - & - & - \\
\hline & Cognitive demands & -0.03 & 0.06 & -0.03 & -0.54 & 0.59 & - & - & - & - \\
\hline & Autonomy & -0.07 & 0.05 & -0.07 & -1.30 & 0.20 & - & - & - & - \\
\hline & Support & -0.04 & 0.05 & -0.05 & -0.89 & 0.38 & - & - & - & - \\
\hline & Developmental possibilities & -0.02 & 0.05 & -0.02 & -0.40 & 0.69 & - & - & - & - \\
\hline \multirow[t]{11}{*}{4} & (Constant) & 10.96 & 5.56 & - & 1.97 & $0.05^{*}$ & 28.33 & 0.70 & 0.50 & 0.06 \\
\hline & Age & -0.01 & 0.00 & -0.07 & -1.80 & 0.07 & - & - & - & - \\
\hline & Gender & -0.08 & 0.05 & -0.06 & -1.50 & 0.13 & - & - & - & - \\
\hline & Work pressure & 0.19 & 0.05 & 0.21 & 4.04 & $0.00 *$ & - & - & - & - \\
\hline & Emotional demands & 0.45 & 0.05 & 0.40 & 8.43 & $0.00 *$ & - & - & - & - \\
\hline & Cognitive demands & -0.04 & 0.05 & -0.04 & -0.79 & 0.43 & - & - & - & - \\
\hline & Autonomy & -0.02 & 0.05 & -0.02 & -0.44 & 0.66 & - & - & - & - \\
\hline & Support & -0.01 & 0.05 & -0.01 & -0.11 & 0.91 & - & - & - & - \\
\hline & Developmental possibilities & 0.01 & 0.05 & 0.01 & 0.24 & 0.81 & - & - & - & - \\
\hline & Mastery & -0.03 & 0.04 & -0.04 & -0.71 & 0.48 & - & - & - & - \\
\hline & Control & -0.07 & 0.04 & -0.09 & -1.55 & 0.12 & - & - & - & - \\
\hline
\end{tabular}

$\mathrm{SE}$, standard error; $t, t$-statistic; $p$, statistical significance; $F$, $F$-statistic; $R$, square root of R-square (correlation between the observed and predicted values of the dependent variable); $R^{2}$, proportion of variance in the dependent variable explained by the independent variables; $\Delta R^{2}$, change in percentage variance explained by next step in model.

of variance in the dependent varia
$*$, Statistically significant $p \leq 0.05$ 
things) experience less work-religion and/or spirituality interference. Autonomy and development possibilities are therefore important resources that could assist employees in spending more quality time with their children and on religious and/or spiritual activities. The results are consistent with previous research, which found that job demands and a lack of job resources are important predictors of negative WHI (Dikkers et al., 2007; Geurts \& Demerouti, 2003; Mostert, 2009; Mostert \& Oosthuizen, 2006; Peeters et al., 2005; Van Aarde \& Mostert, 2008).

With regard to the relationship between recovery experiences and the four work-nonwork interference dimensions, the results showed different patterns of relationships. Specifically, it seems that the relaxation and mastery recovery experiences significantly predicted lower work-parent interference. Relaxation is a state of low activity and it increases positive emotions (Stone, Kennedy-Moore \& Neale, 1995). Thus, when an individual relaxes, positive emotions will help decrease negative emotions resulting from job demands (Frederickson, 2000; Sonnentag \& Fritz, 2007). It can therefore be assumed that a relaxed parent will be less stressed and frustrated, and will be able to spend more quality time with his or her child(ren) and also have more patience with his or her child(ren). The employees' work will thus interfere less with the relationship between them and their child(ren) if the person relaxes adequately by using different methods, such as reading a book or taking a walk (Fritz \& Sonnentag, 2006).

Furthermore, mastery experiences during off-job time will also increase positive mood (Parkinson \& Totterdell, 1999). When an individual is engaged in mastery activities, he or she builds new internal resources such as skills, competencies and effectiveness (Bandura, 1997), which could help the individual to recover more effectively from job stress caused by high demands. Parents who build more skills, competencies and self-efficacy could feel that they are more reliable parents because of the internal resources they have developed and promoted. In terms of different work-family conflicts that exist (Geurts \& Demerouti, 2003), relaxation and mastery experiences will also reduce strainbased conflict. When an individual faces high job demands that create tension, anxiety, fatigue, irritability, and so forth, it makes it difficult for the individual to fulfil family demands (Geurts et al., 1999), and more specifically the demands that the parental role requires. Therefore, when an individual recovers adequately through relaxation and mastery experiences, the tension that spills over to the children will be decreased.

TABLE 4: Multiple regression analysis with work-domestic interference as dependent variable.

\begin{tabular}{|c|c|c|c|c|c|c|c|c|c|c|}
\hline \multirow[t]{2}{*}{ Model } & \multirow[t]{2}{*}{ Independent variables } & \multicolumn{2}{|c|}{$\begin{array}{l}\text { Unstandardised } \\
\text { coefficients }\end{array}$} & \multirow{2}{*}{$\begin{array}{c}\begin{array}{c}\text { Standardised } \\
\text { coefficients }\end{array} \\
\text { Standardised Beta }(\boldsymbol{\beta})\end{array}$} & \multirow[t]{2}{*}{$t$} & \multirow[t]{2}{*}{$p$} & \multirow[t]{2}{*}{$F$} & \multirow[t]{2}{*}{$R$} & \multirow[t]{2}{*}{$R^{2}$} & \multirow[t]{2}{*}{$\Delta R^{2}$} \\
\hline & & Beta $(\beta)$ & SE & & & & & & & \\
\hline \multirow[t]{3}{*}{1} & (Constant) & 5.30 & 9.18 & - & 0.58 & 0.56 & 2.64 & 0.12 & 0.02 & 0.02 \\
\hline & Age & -0.00 & 0.01 & -0.03 & -0.49 & 0.62 & - & - & - & - \\
\hline & Gender & 0.20 & 0.09 & 0.12 & 2.29 & $0.02 *$ & - & - & - & - \\
\hline \multirow[t]{6}{*}{2} & (Constant) & 3.40 & 7.46 & - & 0.46 & 0.65 & 41.95 & 0.61 & 0.37 & 0.36 \\
\hline & Age & -0.00 & 0.00 & -0.02 & -0.46 & 0.64 & - & - & - & - \\
\hline & Gender & 0.20 & 0.70 & 0.13 & 2.91 & $0.00 *$ & - & - & - & - \\
\hline & Work pressure & 0.51 & 0.06 & 0.47 & 8.53 & $0.00 *$ & - & - & - & - \\
\hline & Emotional demands & 0.38 & 0.07 & 0.28 & 5.67 & $0.00 *$ & - & - & - & - \\
\hline & Cognitive demands & -0.13 & 0.07 & -0.09 & -1.74 & 0.08 & - & - & - & - \\
\hline \multirow[t]{8}{*}{3} & (Constant) & 3.84 & 7.40 & - & 0.52 & 0.61 & 27.98 & 0.62 & 0.39 & 0.02 \\
\hline & Age & -0.00 & 0.00 & -0.02 & -0.48 & 0.63 & - & - & - & - \\
\hline & Gender & 0.18 & 0.07 & 0.11 & 2.52 & $0.01 *$ & - & - & - & - \\
\hline & Emotional demands & 0.34 & 0.07 & 0.24 & 4.73 & $0.00 *$ & - & - & - & - \\
\hline & Cognitive demands & -0.09 & 0.07 & -0.07 & -1.29 & 0.20 & - & - & - & - \\
\hline & Autonomy & -0.16 & 0.07 & -0.13 & -2.33 & $0.02 *$ & - & - & - & - \\
\hline & Support & 0.01 & 0.06 & 0.01 & 0.10 & 0.92 & - & - & - & - \\
\hline & Developmental Possibilities & -0.03 & 0.06 & -0.02 & -0.47 & 0.64 & - & - & - & - \\
\hline \multirow[t]{11}{*}{4} & (Constant) & 10.19 & 6.93 & - & 1.47 & 0.14 & 27.61 & 0.70 & 0.49 & 0.10 \\
\hline & Age & -0.00 & 0.00 & -0.05 & -1.25 & 0.21 & - & - & - & - \\
\hline & Gender & 0.14 & 0.07 & 0.09 & 2.15 & $0.03 *$ & - & - & - & - \\
\hline & Work pressure & 0.37 & 0.06 & 0.34 & 6.50 & $0.00 *$ & - & - & - & - \\
\hline & Emotional demands & 0.29 & 0.07 & 0.21 & 4.43 & $0.00 *$ & - & - & - & - \\
\hline & Cognitive demands & -0.10 & 0.07 & -0.07 & -1.55 & 0.12 & - & - & - & - \\
\hline & Autonomy & -0.09 & 0.06 & -0.07 & -1.34 & 0.18 & - & - & - & - \\
\hline & Support & 0.06 & 0.06 & 0.05 & 1.03 & 0.31 & - & - & - & - \\
\hline & Developmental possibilities & 0.03 & 0.06 & 0.03 & 0.50 & 0.62 & - & - & - & - \\
\hline & Mastery & -0.09 & 0.05 & -0.11 & -1.87 & 0.06 & - & - & - & - \\
\hline & Control & -0.13 & 0.05 & -0.14 & -2.50 & $0.01 *$ & - & - & - & - \\
\hline
\end{tabular}

$\mathrm{SE}$, standard error; $t, t$-statistic; $p$, statistical significance; $F$, -statistic; $R$, square root of R-square (correlation between the observed and predicted values of the dependent variable); $R^{2}$, proportion of variance in the dependent variable explained by the independent variables; $\Delta R^{2}$, change in percentage variance explained by next step in model.

$*$ variance in the dependent variabistically significant $p \leq 0.05$
, Statis 
Psychological detachment and relaxation were the recovery experiences significantly associated with lower work-spouse interference. Employees who detach psychologically from work avoid stress related to work by focusing on other types of activities and thoughts different from work issues (Parkinson \& Totterdell, 1999; Sonnentag \& Fritz, 2007). Psychological detachment from work could therefore result in a better mood and less fatigue after work (Sonnentag \& Bayer, 2005). Thus, when an individual detaches psychologically from work during leisure time, he or she can engage in meaningful activities with his or her spouse. Because fatigue levels are decreased, more time can be spent together in the evenings when most people tend to have free time (Moreno-Jiménez et al., 2009; Sonnentag \& Bayer, 2005). It could further imply that an individual can also concentrate on a conversation with a spouse instead of having thoughts about work, and can therefore reconnect with his or her spouse (Sonnentag \& Fritz, 2007). If an employee frequently has to attend to business issues during family time or constantly thinks about work when he or she is supposed to spend time with family it can negatively influence the nonwork domain, specifically the employee's spouse, who's reaction will more than likely be negative (Moreno-Jiménez et al., 2009). Being psychologically detached from work will thus result in an employee experiencing less interference between the work and spousal domain, because of the mental availability to the spouse. Similarly, relaxation increases positive affect and decreases the effects of negative emotions (Frederickson, 2000; Sonnentag \& Fritz, 2007). Thus, if an individual is relaxed, he or she can spend more quality time with his or her spouse on a relaxed and positive level. Strain-based conflict will therefore be decreased if an employee psychologically detaches from work and relaxes, resulting in being a more attentive spouse (Geurts et al., 1999).

Relaxation and control significantly predicted lower work-domestic interference. Many people relax through participating in activities that put few social demands on them, that require little or no intellectual and physical effort and that are not a challenge for them (Tinsley \& Eldredge, 1995). Many people experience relaxation through performing domestic chores. Furthermore, having control in off-job time means that an individual has a choice which domestic actions he or she would like to carry out, as well as how and when to pursue the preferred action (Sonnentag \& Fritz, 2007). Thus, whilst performing the preferred domestic actions, individuals get the opportunity to re-evaluate potential stressful situations, which can lead to higher psychological

TABLE 5: Multiple regression analysis with work-religion and/or spirituality interference as dependent variable.

\begin{tabular}{|c|c|c|c|c|c|c|c|c|c|c|}
\hline \multirow[t]{2}{*}{ Model } & \multirow[t]{2}{*}{ Independent variables } & \multicolumn{2}{|c|}{$\begin{array}{l}\text { Unstandardised } \\
\text { coefficients }\end{array}$} & \multirow{2}{*}{$\begin{array}{c}\begin{array}{c}\text { Standardised } \\
\text { coefficients }\end{array} \\
\text { Standardised Beta }(\boldsymbol{\beta}) \\
\end{array}$} & \multirow[t]{2}{*}{$t$} & \multirow[t]{2}{*}{$p$} & \multirow[t]{2}{*}{$F$} & \multirow[t]{2}{*}{$R$} & \multirow[t]{2}{*}{$R^{2}$} & \multirow[t]{2}{*}{$\Delta R^{2}$} \\
\hline & & Beta $(\beta)$ & SE & & & & & & & \\
\hline \multirow[t]{3}{*}{1} & (Constant) & 4.24 & 6.37 & - & 0.67 & 0.51 & 0.54 & 0.06 & 0.00 & 0.00 \\
\hline & Age & -0.00 & 0.00 & -0.03 & -0.60 & 0.55 & - & - & - & - \\
\hline & Gender & -0.04 & 0.06 & -0.04 & -0.74 & 0.46 & - & - & - & - \\
\hline \multirow[t]{6}{*}{2} & (Constant) & 5.07 & 5.69 & - & 0.89 & 0.37 & 21.30 & 0.48 & 0.23 & 0.23 \\
\hline & Age & -0.00 & 0.00 & -0.04 & -0.90 & 0.37 & - & - & - & - \\
\hline & Gender & -0.05 & 0.05 & -0.04 & -0.94 & 0.35 & - & - & - & - \\
\hline & Work pressure & 0.18 & 0.05 & 0.25 & 4.04 & $0.00 *$ & - & - & - & - \\
\hline & Emotional demands & 0.32 & 0.05 & 0.33 & 6.20 & $0.00 *$ & - & - & - & - \\
\hline & Cognitive demands & -0.04 & 0.06 & -0.04 & -0.70 & 0.48 & - & - & - & - \\
\hline \multirow[t]{8}{*}{3} & (Constant) & 5.72 & 5.61 & - & 1.02 & 0.31 & 15.65 & 0.51 & 0.26 & 0.03 \\
\hline & Age & -0.00 & 0.00 & -0.05 & -1.00 & 0.32 & - & - & - & - \\
\hline & Gender & -0.06 & 0.05 & -0.05 & -1.03 & 0.30 & - & - & - & - \\
\hline & Emotional demands & 0.29 & 0.05 & 0.30 & 5.32 & $0.00 *$ & - & - & - & - \\
\hline & Cognitive demands & -0.02 & 0.05 & -0.02 & -0.41 & 0.68 & - & - & - & - \\
\hline & Autonomy & -0.19 & 0.05 & -0.22 & -3.74 & $0.00 *$ & - & - & - & - \\
\hline & Support & 0.00 & 0.05 & 0.00 & -0.02 & 0.99 & - & - & - & - \\
\hline & Developmental possibilities & 0.08 & 0.05 & 0.10 & 1.77 & 0.08 & - & - & - & - \\
\hline \multirow[t]{11}{*}{4} & (Constant) & 8.33 & 5.52 & - & 1.51 & 0.13 & 13.45 & 0.56 & 0.32 & 0.06 \\
\hline & Age & -0.00 & 0.00 & -0.06 & -1.37 & 0.17 & - & - & - & - \\
\hline & Gender & -0.07 & 0.05 & -0.06 & -1.31 & 0.19 & - & - & - & - \\
\hline & Work pressure & 0.11 & 0.05 & 0.14 & 2.37 & $0.02 *$ & - & - & - & - \\
\hline & Emotional demands & 0.27 & 0.05 & 0.28 & 5.02 & $0.00 *$ & - & - & - & - \\
\hline & Cognitive demands & -0.03 & 0.05 & -0.03 & -0.51 & 0.61 & - & - & - & - \\
\hline & Work autonomy & -0.15 & 0.05 & -0.17 & -2.99 & $0.00 *$ & - & - & - & - \\
\hline & Support & 0.03 & 0.05 & 0.04 & 0.73 & 0.47 & - & - & - & - \\
\hline & Developmental possibilities & 0.10 & 0.05 & 0.13 & 2.17 & $0.03 *$ & - & - & - & - \\
\hline & Mastery & -0.06 & 0.04 & -0.09 & -1.44 & 0.15 & - & - & - & - \\
\hline & Control & -0.08 & 0.04 & -0.13 & -1.89 & 0.06 & - & - & - & - \\
\hline
\end{tabular}

$\mathrm{SE}$, standard error; $t, t$-statistic; $p$, statistical significance; $F$, $F$-statistic; $R$, square root of R-square (correlation between the observed and predicted values of the dependent variable); $R^{2}$, proportion of variance in the dependent variable explained by the independent variables; $\Delta R^{2}$, change in percentage variance explained by next step in model.

$*$, Statistically significant $p \leq 0.05$ 
well-being and lower stress levels (Lazarus, 1966). Having control is associated with positive affect and happiness (Burger, 1989; Larson, 1989) and an individual's well-being is increased when he or she feels in control of significant life domains (Bandura, 1997). A study carried out by Griffin, Fuhrer, Stansfeld and Marmot (2002) showed that women who experienced low control at home had higher levels of depression over a period of time than women with high control at home. Similarly, men who experienced low control at home showed higher levels of depression and anxiety than men with high control at home. When an individual experiences control, it satisfies the urge of wanting to be in control because of promoted self-efficacy and feelings of competence; this in turn increases well-being (Sonnentag \& Fritz, 2007). It can therefore be assumed that strain-based conflict will be decreased through relaxation and control recovery experiences, because if an employee recovers adequately, fatigue will be reduced, giving an individual more energy for domestic activities. From the results in this study, it also seems as though individuals who exert control in off-job time experience less interference between the work and domestic domain.

Psychological detachment also significantly predicted lower work-religion and/or spirituality interference. As previously said, psychological detachment implies that an individual disengages mentally from work (Sonnentag \& Fritz, 2007). By doing so, an individual will be able to spend more time on religious activities without having work-related thoughts and tasks interfering with activities that are meant to be sacred. It is therefore important for individuals who want to engage in religious and/or spiritual activities after hours to mentally forget about work, distance themselves from work and not think about work at all. This will most likely enhance the quality of their religious and/or spiritual experiences.

Recovery refers to experiences that reduce tension and stress caused by everyday demands (Nýlen et al., 2007). According to the E-R model, load reactions build up in an employee who experiences high job demands (i.e. high work pressure and emotional demands) and a lack of resources (i.e. autonomy), and thus interference between the work domain and nonwork domain will develop (Meijman \& Mulder, 1998). Based on this principle of the E-R model, the results of this study suggest that employees who face high job demands and a lack of resources to effectively deal with the demands do indeed build up negative load reactions that will spill over to the nonwork domain. Therefore, employees need to recover from the tension and stress caused by demands and a lack of resources, otherwise they will experience W-NWI, which could eventually have an effect on their health (Geurts et al., 2005; Geurts et al., 1999) and overall well-being (Sonnentag \& Zijlstra, 2006). However, recovery from high demands is needed to decrease the load reactions that develop in the work domain and are carried over to the nonwork domain (De Croon et al., 2004; Eby et al., 2005, Geurts et al., 2003). Certain recovery experiences have been shown, in this study, to alleviate interference between certain work and nonwork domains.
Limitations of this study should be highlighted. The first limitation of this study was the use of a cross-sectional design, which implies that causal relationships could not be determined amongst the variables. A longitudinal design or diary approach could have demonstrated stronger causal relations and conclusions. The second limitation was that only self-reported questionnaires were used to obtain research. This may lead to common-method variance. This is problematic because the phenomenon under investigation becomes hard to differentiate from measurement artefacts (Avolio \& Bass, 1991; Hufnagel \& Conca, 1994). The last limitation of this study was that the sample focused mostly on white employees in the TEI (because they consitute the majority of employees in this institution), which can have an effect, as the sample did not represent various races.

Not withstanding the limitations, various recommendations can be made for the individual as well as the tertiary institution and Human Resources (HR) manager. It is important for both the employee and the HR manager to understand the extent of the high demands and lack of resources that cause W-NWI and the impact that recovery experiences have on employees to help them cope, as both parties are affected by its implications.

In terms of alleviating work pressure and promoting W-NWI, primary interventions should be put in place. In order to do this, the HR manager can re-examine employees' job descriptions to ensure realistic staff-workload ratios. Possible reasons for the perceived high work pressures could be explored and possible solutions which will result in the decrease of work pressure should also be investigated by the HR manager. HR managers can address high work pressure issues with employees in their work performance meetings, determining where the problem areas are and giving it the necessary attention. By developing employees' self-management techniques, W-NWI can also be decreased. In terms of the high emotional demands, it is crucial that possible reasons in the workplace should also be investigated and primary interventions should be in place to prevent aspects that cause emotional demands. On a secondary and tertiary level, training with regard to emotional aspects such as emotional intelligence and/or coping with emotions could be implemented. The development of employees' abilities, competencies and skills can help them cope with their emotional demands, ultimately not only improving their work performance but also their W-NWI. Work-family facilities, for instance professional and affordable childcare facilities on the premises and flexible working hours could also be provided, which will help employees balance their work life and nonwork life (De Klerk \& Mostert, 2010). Other managerial actions such as revision of policies concerning flexible working times and childcare facilities could be developed.

With regard to the job resources, autonomy and developmental possibilities predicted the decrease in negative interference between the work and nonwork domains. Managers could therefore give employees more 
freedom in doing their work, deciding how much time they want to spend on a certain activity and give employees the opportunity to be creative and innovative in their work. Job developmental possibilities can be increased or ensured, by performance management taking place on a regular basis throughout the year to monitor the performance and effective and sufficient work of employees, putting them in line for incentives such as bonuses. Management should also communicate the development opportunities that exist (e.g. promotions or support for further studies). This can motivate employees to be more engaged and make them feel more valued.

With regard to recovery strategies, HR Managers can, for instance, arrange counselling and recovery leave for employees who are at risk of burnout or health implications. On an individual level, the recovery experiences (psychological detachment, relaxation, mastery and control) that are significantly related to W-NWI could be explained and promoted. Organisations as well as the individual should understand how important it is to recover from work. Employees should be made aware of the importance of recovery, the recovery process and the different strategies and experiences that exist to promote and implement recovery.

The following recommendations can be made for future research. Firstly, it is recommended that the study be expanded to other occupations, in other words, other than the employees of a TEI. Every occupation has its own challenges, advantages and disadvantages which influence not only the interference between the work and nonwork, but also the level of recovery that is required. In terms of recovery experiences, future research may show that different experiences are needed in different occupation groups in order to recover.

Various perspectives of individuals who are involved in the work-family dyad can also be taken into consideration. The current study focused only on the individuals' own opinions and perspectives. It can give added insight when the spouse's or child(ren)'s perspectives are known, as organisations only tend to view the work and the individual as the unit of analysis (De Klerk \& Mostert, 2010). Organisations can further examine the crossover effect of spouses and families in work-nonwork interference as a unit of analysis as this can increase our understanding of the complexities of multiple roles in different domains. The use of longitudinal research designs or diary studies is recommended for future research. Longitudinal designs are used to study change on the same units over a period of time, or repeatedly (e.g. individuals, groups, organisations) (Ployhart \& Vandenberg, 2010) and diary studies assess data over a period of time (e.g. seven days). Thus, longitudinal designs may be used to validate the hypothesised causalities of the relationships further and to determine if the relationships hold true over time.

Also, the current study focused exclusively on the negative interference between the work and nonwork domains.
However, it is also important to investigate the positive interaction between the work and nonwork domains. Individuals who experience positive work-nonwork interference are more engaged with their work and experience less burnout (Montgomery et al., 2003; Mostert, 2006; Mostert, Cronje \& Pienaar, 2006), resulting in higher productivity (Moncrieff \& Pomerleau, 2000) and less absenteeism (Väänänen et al., 2004). Thus, positive interaction between the work and the nonwork domain has advantages for the individual as well as for the organisation.

\section{Conclusion}

The general objective of this study was to investigate the impact of work characteristics and recovery strategies on four types of work-nonwork interference. A cross-sectional survey design was used with a population of 366 married employees with children working at a Tertiary Education Institution (TEI) in the North West Province. The results showed that work pressure and emotional demands significantly predicted all four of the work-nonwork role interference dimensions. Of the job resources, lack of autonomy predicted work-parent interference and work-religion and/ or spirituality interference, whilst a lack of development possibilities predicted work-religion and/or spirituality interference. Recovery experiences also played a significant role in predicting work-nonwork interference. Relaxation and mastery recovery experiences significantly predicted lower work-parent interference. A lack of psychological detachment and relaxation were significantly associated with lower work-spouse interference. Relaxation and control significantly predicted lower work-domestic interference, whilst psychological detachment significantly predicted lower work-religion and/or spirituality interference.

\section{Acknowledgements Authors' contributions}

J.O. gathered the data, prepared the sample and wrote the manuscript. K.M. was the project leader and was responsible for the experimental and project design, statistical analyses and supervision in the writing of the article. She was also involved in conceptual contributions of the article. F.E.K. coordinated data gathering, made conceptual contributions and assisted with the interpretation of the results.

\section{References}

Allen, T.D., Herst, D.E., Bruck, C.S., \& Sutton, M. (2000). Consequences associated with work-to-family conflict: A review and agenda for future research. Journal of Occupational Health Psychology, 5, 278-308. http://dx.doi.org/10.1037/10768998.5.2.278, PMid:10784291

Aryee, S. (1992). Antecedents and outcome of work-family conflict among married professional women: Evidence from Singapore. Human Relations, 45, 813-837. http://dx.doi.org/10.1177/001872679204500804

Avolio, B.J., \& Bass, B.M. (1991). Identifying common methods variance with data collected from a single source: An unresolved sticky issue. Journal of Management, 17, 571-587.

Bakker, A.B., Demerouti, E., \& Euwema, M.C. (2005). Job resources buffer the impact of job-demands on burnout. Journal of Occupational Health Psychology, 10(2), 170-180. http://dx.doi.org/10.1037/1076-8998.10.2.170, PMid:15826226

Bakker, A.B., Demerouti, E. \& Schaufeli, W.B. (2003a). The socially induced burnout model. In A.M. Columbus (Eds.), Leading edge research in cognitive psychology, (pp. 46-62). New York: Nova Science Publishers. 
Bakker, A.B., Demerouti, E., \& Schaufeli, W.B. (2003b). Dual processes at work in a call centre: An application of the job demands-resources model. European Journal of Work and Organizational Psychology, 12, 393-417. http://dx.doi. Journal of Work and Organizationa
org/10.1080/13594320344000165

Bakker, A.B., Demerouti, E., Taris, T., Schaufeli, W.B., \& Schreurs, P. (2003c). A multi-group analysis of the Job Demands-Resources model in four home-care organizations. International Journal of Stress Management, 10, 16-38. http:// dx.doi.org/10.1037/1072-5245.10.1.16

Bakker, A.B., Demerouti, E., \& Verbeke, W. (2004). Using the Job Demands-Resources model to predict burnout and performance. Human Resource Management, 43, 83-104. http://dx.doi.org/10.1002/hrm.20004

Bakker, A.B., \& Geurts, S.A.E. (2004). Toward a dual-process model of workhome interference. Work and Occupations, 31(3), 345-366. http://dx.doi. org $/ 10.1177 / 0730888404266349$

Bandura, A. (1997). Self-efficacy: The exercise of control. New York: Freeman.

Barkhuizen, N., \& Rothmann, S. (2008a). Occupational stress of academic staff in South African higher education institutions. South African Journal of Psychology, 38(2), 321-336.

Barkhuizen, N., \& Rothmann, S. (2008b). Burnout of academic staff in South African higher education institutions. South African Journal of Higher Education, 22(2), 439-456.

Bellavia, G., \& Frone, M.R. (2004). Work-family conflict. In K. Barling \& M.R. Frone (Eds.), Handbook of work stress, (pp. 113-147). Thousand Oaks, CA: Sage.

Boyar, S.L., Maertz, C.P., Mosley, D.C., \& Carr, J.C. (2008). The impact of work/family demand on work-family conflict. Journal of Managerial Psychology, 23, 215-235. http://dx.doi.org/10.1108/02683940810861356

Brosschot, J.F., Pieper, S., \& Thayer, J.F. (2005). Expanding stress theory: Prolonged activation and perseverative cognition. Psychoneuroendocrinology, 30, 10431049. http://dx.doi.org/10.1016/j.psyneuen.2005.04.008, PMid:15939546

Bryman, A., \& Bell, E. (2003). Business research methods. (2nd edn.). New York: Oxford University Press.

Burger, J.M. (1989). Negative reactions to increases in perceived personal control. Journal of Personality and Social Psychology, 56, 246-256. http://dx.doi. org/10.1037/0022-3514.56.2.246

Burke, P.J. (1980). The self: Measurement requirements from an interactionis perspective. Social Psychology Quarterly, 43(1), 18-29. http://dx.doi. org/10.2307/3033745

Byron, K. (2005). A meta-analytic review of work-family conflict and its antecedents. Journal of Vocational Behavior, 67, 169-198. http://dx.doi.org/10.1016/j. jvb.2004.08.009

Coetzee, S.E., \& Rothmann, S. (2005). Occupational stress, organisational commitment and ill-health of employees at a higher education institution in South-Africa. $S A$ Journal of Industrial Psychology/SA Tydskrif vir Bedryfsielkunde, 31(1), 47-54.

Cohen, J. (1988). Statistical power analysis for the behavioural sciences. (2nd edn.). Orlando, FL: Academic Press.

Day, A.L., \& Chamberlain, T.C. (2006). Committing to your work, spouse and children: Implications for work-family conflict. Journal of Vocational Behavior, 68, 116-130. http://dx.doi.org/10.1016/j.jvb.2005.01.001

De Croon, E.M., Sluiter, J.K., Blonk, R.W.B., Broersen, J.P.J., \& Frings-Dresen, M.H.W. (2004). Stressful work, psychological job strain and turnover. A 2-year prospective cohort study of truck drivers. Journal of Applied Psychology, 89, 442-454. http:// dx.doi.org/10.1037/0021-9010.89.3.442, PMid:15161404 De Klerk, M., \& Mostert, K. (2010). Work-home interference: Examining socio-
demographic predictors in the South African context. SA Journal of Human Resource Management/SA Tydskrif vir Menslikehulpbronbestuur, 8(1), 1-10.

Demerouti, E., Bakker, A.B., Nachreiner, F., \& Schaufeli, W.B. (2001). The Job-Demands Resources model of burnout. Journal of Applied Psychology, 86, 499-512. http:// dx.doi.org/10.1037/0021-9010.86.3.499, PMid:11419809

Demerouti, E., Bakker, A.B., \& Voydanoff, P. (2010). Does home life interfere with or facilitate job performance? European Journal of Work and Organisationa Psychology, 19(2), 128-149. http://dx.doi.org/10.1080/13594320902930939

Demerouti, E., \& Geurts, S.A.E. (2004). Towards a typology of work-home interaction. Community, Work \& Family, 7(3), 285-309. http://dx.doi.org/10.1080/13668800 42000295727, PMid:2576907

Demerouti, E., Geurts, S.A.E., \& Kompier, M.A.J. (2004). Positive and negative workhome interaction: Prevalence and correlates. Equal Opportunities International 23(1), 6-35. http://dx.doi.org/10.1108/02610150410787837

Dikkers, J.S.E., Geurts, S.A.E., Kompier, M.A.J., Taris, T.W., Houtman, I.L.D., \& Van den Heuvel, F. (2007). Does workload cause work-home interference or is it the other way around? Stress \& Health, 23, 303-314. http://dx.doi.org/10.1002/smi.1151

Duxbury, L. (2004). Dealing with work-life issues in the workplace: Standing still is not an option. The Don Wood Lecture in Industrial Relations. Canada: Industrial not an option. The
Relations Centre.

Eby, L.T., Casper, W.J., Lockwood, A., Bordeaux, C., \& Brinley, A. (2005). Work and family research in IO/OB: Content analysis and review of the literature (19802002). Journal of Vocational Behavior, 66(1), 87-97.

Eden, D. (2001). Vacations and other respites: Studying stress on and off the job. In C.L. Coopers \& I.T. Robertson (Eds.), International review of industrial and organisational psychology, (Vol. 16, pp. 121-146). New York: Wiley.

Fredrickson, B.L. (2000). The undoing effect of positive emotions. Motivation and Emotion, 24, 237-258. http://dx.doi.org/10.1023/A:1010796329158, PMid:21731120, PMCid:3128334
Fritz, C., \& Sonnentag, S. (2005). Recovery, health and ob performance: Effects of weekend experiences, Journal of Occupational Health Psychology 10(3), 187weekend experiences. Journal of Occupational Health Psychology,
199. http://dx.doi.org/10.1037/1076-8998.10.3.187, PMid:16060723

Fritz, C., \& Sonnentag, S. (2006). Recovery, well-being, and performance-related outcomes: The role of workload and vacation experiences. Journal of Applied Psychology, 91, 936-945. http://dx.doi.org/10.1037/0021-9010.91.4.936, PMid: 16834516

Frone, M.R., Russel, M., \& Coopers, M.L. (1997). Relation of work-family conflict to health outcomes: a four-year longitudinal study of employed parents. Journal of Occupational and Organizational Psychology, 70, 325-335. http://dx.doi. of Occupational and Organizational Psych

Fox, M.L., Tange, A., \& Perez, L. (2008). Conflict, workload and health: The moderation effects of recovery experiences. Proceedings presented at the Midwest Academy of Management Conference, 2-4 October 2008. St Louis, Missouri.

Geurts, S.A.E., \& Demerouti, E. (2003). Work/non-work interface: A review of theories and findings. In M. Schabracq, J. Winnubst \& C.L. Cooper (Eds.), Handbook of Work and Health Psychology, (pp. 279-312). Chichester: Wiley.

Geurts, S.A.E., Kompier, M.A.J., Roxburgh, S., \& Houtmann, I.D. (2003). Does workhome interference mediate the relationship between workload and well-being? Journal of Vocational Behavior, 63, 532-559. http://dx.doi.org/10.1016/S00018791(02)00025-8

Geurts, S.A.E., Rutte, C., \& Peeters, M. (1999). Antecedents and consequences of work-home interference among medical residents. Social Science and Medicine, 48, 1135-1148. http://dx.doi.org/10.1016/S0277-9536(98)00425-0

Geurts, S.A.E., \& Sonnentag, S. (2006). Recovery as an explanatory mechanism in the relation between acute stress reactions and chronic health impairment. Scandinavian Journal of Work, Environment \& Health, 32(6), 482-492. PMid:17173204

Geurts, S.A.E., Taris, T.W., Kompier, M.A.J., Dikkers, J.S.E., Van Hooff, M.L.M., \& Kinnunen, U.M. (2005). Work-home interaction from a work psychological perspective: Development and validation of a new questionnaire, the SWING. Work and Stress, 19(4), 319-339. http://dx.doi.org/10.1080/02678370500410208

Government of Western Australia, Department of Health (2007). Achieving work-life balance: Retention and attraction strategies for WA Health. Retrieved February 16, 2011, from http://www.health.wa.gov.au/worklifebalance/docs/retention 16, 2011, from http://W

Grandey, A., \& Cropanzano, R. (1999). The conservation of resources model applied to work-family conflict and strain. Journal of Vocational Behavior, 54, 350-370. http://dx.doi.org/10.1006/jvbe.1998.1666

Greenhaus, J.H., \& Beutell, N.J. (1985). Sources of conflict between work and family roles. Academy of Management Review, 10(1), 76-88. http://dx.doi.org/10.5465/ AMR.1985.4277352

Griffin, J.M., Fuhrer, R., Stansfeld, S.A., \& Marmot, M. (2002). The importance of low control at work and home on depression and anxiety: Do these effect vary by gender and social class? Social Science and Medicine, 54, 783-798. http://dx.doi. org/10.1016/S0277-9536(01)00109-5

Grzywacz, J.G., \& Marks, N.F. (2000). Reconceptualizing the work-family interface: An ecological perspective on the correlates of positive and negative spillover between work and family. Journal of Occupational Health Psychology, 5(1), 111between work and family. Journal of Occupational Health Psychology
126. http://dx.doi.org/10.1037/1076-8998.5.1.111, PMid:10658890

Hufnagel, E.M., \& Conca, C. (1994). User response data: The potential for errors and biases. Information System Research, 5, 48-73.

Jackson, L.T.B., Rothmann, S., \& Van de Vijver, F.J.R. (2006). A model of work-related well-being for educators in South Africa. Stress \& Health, 22, 263-274. http:// dx.doi.org/10.1002/smi.1098

Jansen, N., Kant, I., Kirstensen, T.S., \& Nijhuis, F.J. (2003). Antecedents and consequences of work-family conflict: A prospective cohort study. Journal of Occupational and Environmental Medicine, 45(5), 479-491. http://dx.doi. org/10.1097/01.jom.0000063626.37065.e8, PMid:12769054

Janssen, P.P.M., Peeters, M.C.W., De Jonge, J., Houkes, I., \& Tummers, G.E.R. (2004). Specific relationships between job demands, job resources and psychological outcomes and the mediating role of negative work-home interference. Journal outcomes and the mediating role of negative work-home interference. Journal
of Vocational Behavior, 66, 411-429. http://dx.doi.org/10.1016/j.jvb.2003.09.004

Kinnunen, U., \& Mauno, S. (1998). Antecedents and outcomes of work-family conflict among employed women and men in Finland. Human Relations, 51, 157-177. among employed women and men in Finland. H
$\mathrm{http}: / / \mathrm{dx}$.doi.org/10.1177/001872679805100203

Koekemoer, F.E., \& Mostert, K. (2006). Job characteristics, burnout and negative work-home interference. SA Journal of Industrial Psychology/SA Tydskrif vir Bedryfsielkunde, 32(3), 87-97.

Koekemoer, F.E., \& Mostert, K. (2010a). An exploratory study of the interaction between work and personal life: Experiences of South African employees. SA Journal of Industrial Psychology/SA Tydskrif vir Bedryfsielkunde, 36(1), 1-15.

Koekemoer, F.E., \& Mostert, K. (2010b). Work-nonwork interference: Preliminary results on the psychometric properties of a new instrument. SA Journal of Industrial Psychology/SA Tydskrif vir Bedryfsielkunde, 36(1), 1-13.

Koekemoer, F.E., Mostert, K., \& Rothmann, S. Jr, (2010). Interference between work and nonwork roles: The development of a new South African instrume Journal of Industrial Psychology/SA Tydskrif vir Bedryfsielkunde, 36(1), 1-14.

Larson, R. (1989). Is feeling "in control" related to happiness in daily life? Psychological Reports, 64, 775-784. http://dx.doi.org/10.2466/pr0.1989.64.3.775, PMid:2748778

Lazarus, R.S. (1966). Psychological stress and the coping process. New York: McGrawHill. 
Meijman, T.F. (1989). Mentale belasting en werkstress: een arbeidspsychologische benadering. Assen: Van Gorcum.

Meijman, T.F., \& Mulder, G. (1998). Psychological aspects of workload. In P.J. Drenth, H. Thierry \& C.J. de Wolff (Eds.), Handbook of Work and Organizational Psychology, (pp. 5-3). Hove, UK: Psychology Press.

Mesmer-Magnus, J.R., \& Viswesvaran, C. (2005). Convergence between measures of work-to-family and family-to-work conflict: A meta-analytic examination. Journal of Vocational Behaviour, 67, 215-232. http://dx.doi.org/10.1016/j. jvb.2004.05.004

Moncrieff, J., \& Pomeleau, J. (2000). Trends in sickness benefits in Great Britain and the contribution of mental disorders. Journal of Public Health Medicine, 22(1), 59-67. http://dx.doi.org/10.1093/pubmed/22.1.59

Montgomery, A.J., Mostert, K., \& Jackson, L.T.B. (2005). Burnout and health of primary school educators in the North-West Province. South African Journal of Education, 25(4), 266-272.

Montgomery, A.J., Panagopolou, E., \& Benos, A. (2006). Work-family interference as a mediator between job demands and job burnout among doctors. Stress \& Health 22, 203-212. http://dx.doi.org/10.1002/smi.1104

Montgomery, A.J., Peeters, M.C.W., Schaufeli, W.B., \& Den Ouden, M. (2003) Work-home interference among newspaper managers: Its relationship with burnout and engagement. Anxiety, Stress \& Coping, 16, 195-211. http://dx.doi. org/10.1080/1061580021000030535

Moreno-Jiménez, B., Mayo, M., Sanz-Vergel, A.I., Geurts, S.A.E., Rodríguez-Munoz, A., \& Garrosa, E. (2009). Effects of work-family conflict on employees' well-being: The moderating role of recovery strategies. Journal of Occupational Health Psychology, 14(4), 427-440.

Mostert, K. (2006). Work-home interaction as partial mediator between job resources and work engagement. Southern African Business Review, 10(1), 53-74.

Mostert, K. (2008). Time-based and strain-based work-family conflict in the South African Police Service: Examining the relationship with work characteristics and exhaustion. Acta Criminologica, 21(3), 1-18.

Mostert, K. (2009). The balance between work and home: The relationship between work and home demands and ill health of employed females. SA Journal of Industrial Psychology/SA Tydskrif vir Bedryfsielkunde, 35(1), 1-8. http://dx.doi. org/10.4102/sajip.v35i1.743

Mostert, K., Cronje, S., \& Pienaar, J. (2006). Job resources, work engagement and the mediating role of positive work-home interaction of police officers in the North West province. Acta Criminologica, 19, 64-87.

Mostert, K., \& Els, C. (in press). Recovery experiences of employees in a higher education institution: Psychometric properties of the Recovery Experience Questionnaire. SA Journal of Human Resources.

Mostert, K., \& Oosthuizen, B. (2006). Job characteristics and coping strategies associated with negative and positive work-home interference in a nursin environment. South African Journal of Economic Management Sciences, 9(4), 429-443.

Noor, N.M. (2004). Work-family conflict, work- and family- role salience and women's well-being. The Journal of Social Psychology, 144(4), 389-405. http://dx.do org/10.3200/SOCP.144.4.389-406, PMid:15279329

Nunnally, J.C., \& Bernstein, I.H. (1994). Psychometric theory. (3rd edn.). New York: McGraw-Hill.

Nýlen, L., Melin, B., \& Laflamme, L. (2007). Interference between work and outsidework demands relative to health: Unwinding possibilities among full-time and part-time employees. International Journal of Behavioral Medicine, 14(4), 229236

Oldfield, G., \& Mostert, K. (2007). Job characteristics, ill health and negative work home interference in the mining industry. SA Journal of Industrial Psychology/SA Tydskrif vir Bedryfsielkunde, 33(2), 68-75.

Parasuraman, S., Purohit, Y.S., Godshalk, V.M., \& Beutell., N.J. (1996). Work and family variables, entrepreneurial career success, and psychological well-being Journal variables, entrepreneurial career success, and psychological well-being. Journal
of Vocational Behavior, 48, 275-300. http://dx.doi.org/10.1006/jvbe.1996.0025

Parkinson, B., \& Totterdell, P. (1999). Classifying affect-regulation strategies. Cognition and Emotion, 13, 277-303. http://dx.doi.org/10.1080/026999399379285

Peeters, M.C.W., De Jonge, J., Janssen, P.P.M., \& Van der Linden, S. (2004). Work-home interference, job stressors, and employee health in a longitudinal perspective. International Journal of Stress Management, 11(4), 305-322. http://dx.doi. org/10.1037/1072-5245.11.4.305

Peeters, M., Montgomery, A.J., Bakker, A.B., Schaufeli, W.B. (2005). Balancing work and home: How job and home demands are related to burnout. International Journal of Stress Management, 12, 43-61. http://dx.doi.org/10.1037/1072 5245.12.1.43

Ployhart, R.E., \& Vandenberg, R.J. (2010). Longitudinal research: The theory, design and analysis of change. Journal of Management, 36(1), 94-120. http://dx.doi. org/10.1177/0149206309352110

Reitzes, D.C., \& Mutran, E.J. (1994). Multiple roles and identities: Factors influencing self-esteem among middle-aged working men and women. Social Psychology Quarterly, 54(4), 313-325. http://dx.doi.org/10.2307/2787158
Rothmann, S., \& Essenko, N. (2007). Burnout of support staff in a higher education institution in the North West Province. South African Journal of Psychology, 37, institution 1352 .

Schaufeli, W.B., \& Bakker, A.B. (2004). Job demands, job resources, and their relationship with burnout and engagement: A multi-sample study. Journal of Organizational Behavior, 25(3), 293-315. http://dx.doi.org/10.1002/job.248

Siltaloppi, M., Kinnunen, U., \& Feldt, T. (2009). Recovery experiences as moderators between psychosocial work characteristics and occupational well-being. Work \& Stress, 23(4), 330-348. http://dx.doi.org/10.1080/02678370903415572

Simon, R.W. (1992). Parental role strains, salience of parental identity and gender differences in psychological distress. Journal of Health and Social Behaviour, 33 25-35. http://dx.doi.org/10.2307/2136855, PMid:1619256

Small, S.A., \& Riley, D. (1990). Toward a multidimensional assessment of work spillover into family life. Journal of Marriage and the Family, 52, 51-61. http:// dx.doi.org/10.2307/352837

Sonnentag, S., \& Bayer, U. (2005). Switching of mentally: Predictors and consequences of psychological detachment from work during off-job time. Journal of Occupational Health Psychology, 10(4), 393-414. http://dx.doi. org/10.1037/1076-8998.10.4.393, PMid:16248688

Sonnentag, S., \& Fritz, C. (2007). The recovery experience questionnaire: Development and validation of a measure assessing recuperation and unwinding at work. Journal of Occupational Health Psychology, 12, 204-221. http://dx.doi. arg/10.1037/1076-8998.12.3.204, PMid:17638488

Sonnentag, S., \& Geurts, S.A.E. (2009). Methodological issues in recovery research. In S. Sonnentag, P. Perrewe \& D. Gangster (Eds.), Research in Occupational Stress and Well-being: Current perspectives on job-stress recovery, (pp. 1-36). Bingley, UK: JAI Press. http://dx.doi.org/10.1108/S1479-3555(2009)0000007003

Sonnentag, S., \& Kruel, U. (2006). Psychological detachment from work during off-job time: The role of job stressors, job involvement, and recovery-related self-efficacy. European Journal of Work and Organizational Psychology, 15(2), 197-217. http:// dx.doi.org/10.1080/13594320500513939

Sonnentag, S., \& Zijlstra, F.R.H. (2006). Job characteristics and off-job activities as predictors of need for recovery, well-being and fatigue. Journal of Applied Psychology, 91(2), 330-350. http://dx.doi.org/10.1037/0021-9010.91.2.330, PMid:16551187

SPSS Inc. (2009). SPSS 12.0 for Windows. Chicago, IL: SPSS Inc.

Stein, F. (2001). Occupational stress, relaxation therapies, exercise and biofeedback. In F. Stein \& S. Cutler (Eds.), Psychosocial Occupational Therapy: A Holistic Approach, (pp. 235-245). Albany, NY: Delmar.

Stone, A.A., Kennedy-Moore, E., \& Neale, J.M. (1995). Association between daily coping and end-of-day mood. Health Psychology, 14, 341-349. http://dx.doi. org/10.1037/0278-6133.14.4.341, PMid:7556038

Struwig, F.W., \& Stead, G.B. (2001). Planning, designing and reporting research. Cape Town: Pearson Education.

Stryker, S. (1968). Identity salience and role performance: The relevance of symbolic interaction theory for family research. Journal or Marriage and the Family, 30 , 558-564. http://dx.doi.org/10.2307/349494

Thoits, P.A. (1995). Identity-relevant events and psychological symptoms: A cautionary tale. Journal of Health and Social Behaviour, 36(March), 72-82. http://dx.doi. org/10.2307/2137288, PMid:7738329

Tinsley, H.E.A., \& Eldredge, B.D. (1995). Psychological benefits of leisure participation A taxonomy of leisure activities based on their need-gratifying properties. Journa of Counseling Psychology, 42(2), 123-132. http://dx.doi.org/10.1037/0022 0167.42.2.123

Tshabalala, S. (2007). Home and work demands and resources, social support and work-home interaction of Potchefstroom educators. Unpublished master's dissertation, North-West University, Potchefstroom, South Africa.

Väänänen, A., Kevin, M.V., Ala Mursula, L., Pentti, J., Kivimäki, M., \& Vahtera, J. (2004) The double burden of and negative spillover between paid and domestic work: Associations with health among men and women. Women and Health, 4O(3), 1-18.

Van Aarde, A., \& Mostert, K. (2008). Work-home interaction of working females: What is the role of job and home characteristics? SA Journal of Industrial Psychology/SA Tydskrif vir Bedryfsielkunde, 34(3), 1-10.

Van Hooff, M., Geurts, S.A.E., Kompier, M.A.J., Taris, T.W., Houtman, I.L.D., \& Van den Heuvel, F. (2005). Disentangling the causal relationships between work-home interference and employee health. Scandinavian Journal of Work, Environment \& interference and employee health.
Health, 31, 15-29. PMid:15751615

Van den Tooren, M., \& De Jonge, J. (2010). The role of matching job resources in different demanding situations at work: A vignette study. Journal of Occupational and Organizational Psychology, 83, 39-54. http://dx.doi. Occupational and Organization
$\mathrm{org} / 10.1348 / 096317909 \times 462257$

Wilensky, H.L. (1960). Work, careers and social integration. International Socia Science Journal, 12, 543-560.

Wiley, M.G. (1991). Gender, work, and stress: The potential impact of role-identity salience and commitment. The Sociological Quarterly, 32(4), 495-510. http:// dx.doi.org/10.1111/j.1533-8525.1991.tb00150.x 